\title{
Irrigation Termination Thermal Time and Amount on Cotton Lint Yield and Fiber Quality
}

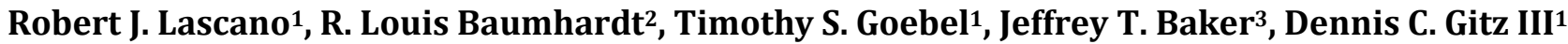 \\ ${ }^{1}$ Wind Erosion and Water Conservation, Cropping Systems Research Laboratory, USDA-ARS*, Lubbock, TX, USA \\ ${ }^{2}$ Soil and Water Management Research, Conservation and Production Research Laboratory, USDA-ARS, Bushland, TX, USA \\ ${ }^{3}$ Wind Erosion and Water Conservation, Cropping Systems Research Laboratory, USDA-ARS, Big Spring, TX, USA \\ Email: Robert.Lascano@ars.usda.gov
}

How to cite this paper: Lascano, R.J., Baumhardt, R.L., Goebel, T.S., Baker, J.T. and Gitz III, D.C. (2017) Irrigation Termination Thermal Time and Amount on Cotton Lint Yield and Fiber Quality. Open Journal of Soil Science, 7, 216-234.

https://doi.org/10.4236/ojss.2017.79016

Received: June 6, 2017

Accepted: September 10, 2017

Published: September 13, 2017

Copyright (c) 2017 by authors and Scientific Research Publishing Inc. This work is licensed under the Creative Commons Attribution International License (CC BY 4.0).

http://creativecommons.org/licenses/by/4.0/ (c) (i) Open Access

\begin{abstract}
Cotton irrigation in the Texas High Plains (THP) is often dictated by the well capacity and not by the water needs of the crop. The source of irrigation-water is the Ogallala aquifer and in many areas of the THP, the water table has declined to well capacities that deliver 1.3 to $>7.6 \mathrm{~mm} / \mathrm{d}$. There is plenty of information on cotton responses to irrigation frequency and amount; however, information on when to terminate irrigation and its effect on cotton lint yield and fiber quality is scarce. Our objective was to evaluate over a 4-year period three irrigation termination thermal times corresponding to cumulative daily heat units $(\Sigma \mathrm{HU})$ of $890{ }^{\circ} \mathrm{C}, 1000{ }^{\circ} \mathrm{C}$ and $1110{ }^{\circ} \mathrm{C}$ from crop emergence, and three levels of irrigation $(2.5,5.1$ and $7.6 \mathrm{~mm} / \mathrm{d})$ on cotton lint yield and fiber quality. Irrigation was applied with a sprinkler system on a 3-day frequency in Lubbock, TX. Results showed that on average the $7.6 \mathrm{~mm} / \mathrm{d}$ level produced the most cotton lint yield regardless of the irrigation termination thermal time. Terminating cotton at $1000-{ }^{\circ} \mathrm{C} \Sigma \mathrm{HU}$ resulted in water savings of 25 to $50 \mathrm{~mm}$ for the 2.5 and $5.1 \mathrm{~mm} / \mathrm{d}$ levels without significantly affecting lint yield. For the $7.6 \mathrm{~mm} / \mathrm{d}$ and terminating at $890-{ }^{\circ} \mathrm{C} \Sigma \mathrm{HU}$ resulted in water savings of 100 to $115 \mathrm{~mm}$. Average fiber length statistically increased with termination thermal time and level. This effect was most significant in years with the least rain and warmer air temperature. Micronaire increased with the termination thermal time in years with $>500 \mathrm{~mm}$ of rain. Average fiber length uniformity and fiber strength were minimally affected by termination thermal time. As irrigation level increased, the average micronaire decreased, and fiber strength increased for the 5.1 and $7.6 \mathrm{~mm} / \mathrm{d}$ irrigation. We concluded that in the THP for well capacities that deliver $2.5-5.1 \mathrm{~mm} / \mathrm{d}$ irrigation can be terminated when the $\Sigma \mathrm{HU}$ reaches about $1000{ }^{\circ} \mathrm{C}$ from emergence without impacting cotton lint yield.
\end{abstract}




\section{Keywords}

Irrigation Scheduling, Semiarid, Limited Water, Texas High Plains, Evapotranspiration

\section{Introduction}

The history of irrigation in Texas is well-documented [1] [2] and irrigation trends in the Texas High Plains (THP) are given by [3] and more recently by [4]. In the THP large-scale irrigation started in 1920's and due to a lack of surface water, irrigators withdrew the groundwater, first with windmills and later with irrigation pumps [5]. With the introduction of the internal combustion engine [6] and in response to the drought known as the Dust Bowl [7] irrigation became an established and practical management tool used in crop production. The source of most of the irrigation water in the THP is the Ogallala Aquifer, which underlies an area of about $450,000 \mathrm{~km}^{2}$ in portions of eight states of the USA [4]. In the THP, the Ogallala Aquifer is largely a closed system where withdrawals exceed recharge leading to a decline of the water table [3] [4] [6] [8]. In certain areas of the THP, the decline in the Ogallala Aquifer water table is leading to well capacities that yield less water than the daily water requirements, evapotranspiration demand, of the crops grown in this area [9] [10].

In response to this decline and to use seasonal rain, the sprinkler irrigation system known as Low Energy Precision Application (LEPA) was developed [11] [12] and evaluated for cotton [13] [14], corn [15] [16] grain sorghum [17] and winter wheat [18]. The LEPA irrigation system was also developed to reduce losses of irrigation water that when applied with overhead sprinklers would evaporate under conditions of low air humidity and high winds, which are common in the THP [11]. Further, LEPA was developed to apply irrigation-water using furrow dikes that provide temporary detention for water, either from rain or irrigation [19] [20] [21]. An additional component of LEPA was to apply water to alternate furrows as a means to reduce hardware costs and without a reduction of crop yield [12] [22]. The LEPA was adapted for well capacities that deliver irrigation amounts that range from 1.3 to $>7.6 \mathrm{~mm} / \mathrm{d}$; however, in the THP it is the well capacity that often dictates the amount of water that is applied regardless of the environmental demand and needs of the crop. The reality is that in some areas of the THP, the only irrigation scheduling option is to continuously water the crop from planting to harvest [9].

In general, the irrigation management of cotton in the THP should consider three factors: 1) rain frequency and amount; 2) the well-capacity and irrigation system used to water the crop, e.g., furrow, sprinkler, LEPA and drip; and 3) irrigation scheduling, including the soil water balance and the physiological response of the crop to water [9]. The main purpose of managing irrigation-water for cotton production is to maximize the quantity of lint and quality of the fiber 
produced per unit of water (e.g., [22] [23] [24]). Currently, in the THP most of the cotton irrigated with LEPA is watered every 3 days, to alternate diked furrows [13] [17]. The amount of water required on a daily basis can be calculated by multiplying a daily reference evapotranspiration $\left(\mathrm{ET}_{\mathrm{o}}\right)$ value [25] by a crop coefficient $\left(K_{c}\right)$. This method is referred to as the "engineering approach" [9] and was first suggested by [26]. Cotton is a perennial species that is cultivated as an annual crop that responds well to frequent, sthree days, deficit irrigation. In the THP, information on cotton irrigation with LEPA with frequent irrigations to alternate rows using furrow dikes is well documented [13] [27]. However, information on when to stop irrigation at the end of the season and how that termination date affects cotton lint yield and fiber quality is not well known. For example, several studies have addressed these effects on the timing of the first irrigation (e.g., [28]) and of the termination (e.g., [29]-[35]) on both lint yield and fiber quality. The effect of both the first and last irrigation on the lint yield of cotton is given by [36]. However, it is difficult to draw conclusions from these studies because the initial and final thermal times of irrigation were based on days after sowing and on calendar days. The exception is the work of [32], where termination thermal times were based on cumulative daily heat units $(\Sigma \mathrm{HU})$ after planting.

Air temperature, based on a threshold of $15.6{ }^{\circ} \mathrm{C}$, is related to the phenological development of cotton and is centered on observations that cotton plants do not grow below this air temperature [37] [38]. Over the growing season $\Sigma H U$ has been used to describe the different stages of cotton development, from seedling emergence to harvest (e.g., [39] [40]). For example, in the THP, typically a cotton plant requires about $280-{ }^{\circ} \mathrm{C} \Sigma \mathrm{HU}$ from emergence to first square and about $560-{ }^{\circ} \mathrm{C} \Sigma \mathrm{HU}$ from the appearance of the first flower to open a cotton boll [41]. An advantage of using $\Sigma \mathrm{HU}$ as the time variable to describe crop development is that it removes the day-to-day temperature variability and thus experimental results obtained in different growing seasons may be compared. The objective of this research was to evaluate three termination thermal times of irrigation for three different amounts (levels) of LEPA irrigation to evaluate their effect on cotton lint yield and fiber quality in the THP.

\section{Materials and Methods}

\subsection{Field Experiments}

These experiments were part of an evaluation of a general system to concurrently measure weather variables, soil temperature and water content, soil heat flux and crop transpiration and to couple these measurements with a mechanistic simulation model as described in detail by [9]. Field experiments were done over a four-year period, from 1996 to 1999, at the facilities of Texas A \& M AgriLife Research and Extension Center in Lubbock, TX (N 33 $41^{\prime} 42^{\prime \prime}$ and W 101 $\left.49^{\circ} 30^{\prime \prime}\right)$. The experimental field was $80 \times 210 \mathrm{~m}$ on an Olton clay loam (fine, mixed, thermic Aridic Paleustolls). The experimental design was a split-plot design with three irrigation levels (whole plots) and three termination thermal times (split-plots). 
Each irrigation level plot was $14 \mathrm{~m}$ wide and $100 \mathrm{~m}$ long and was replicated four times. The irrigation levels were, low $(2.5 \mathrm{~mm} / \mathrm{d})$, medium $(5.1 \mathrm{~mm} / \mathrm{d})$ and high $(7.6 \mathrm{~mm} / \mathrm{d})$ that represent the range of well capacity available from the Ogallala aquifer across the THP [9]. The termination thermal times for irrigation were based on $\sum \mathrm{HU}$ and we selected three values, i.e., $890{ }^{\circ} \mathrm{C}, 1000{ }^{\circ} \mathrm{C}$ and $1110{ }^{\circ} \mathrm{C}$, which are within the range of $\Sigma \mathrm{HU}$ needed for cotton production in the Ogallala Aquifer region of the THP [42]. The cotton crop was irrigated on a three-day frequency with a surface drip system used to simulate LEPA as suggested by [13]. Data were analyzed by ANOVA and means were separated by Fisher's least significant difference (SAS Institute, v. 9.2).

Each year and based on recommendations from the local Texas AgriLife soil testing laboratory, the field was fertilized with $110 \mathrm{~kg} / \mathrm{ha}$ of $\mathrm{N}$ and $45 \mathrm{~kg} / \mathrm{ha}$ of $\mathrm{P}$, which was applied prior to planting. In all years, cotton was planted in bedded rows with furrow dikes, $1.0 \mathrm{~m}$ apart, on an East-West orientation at a density of 120,000 plants/ha. Herbicides prior to planting (Trifluralin and Prometryn) and after planting (Glyphosate applied with a directed spot treatment with a shield) were applied using the recommended rates for cotton on a clay loam soil. In 1996, 1997 and 1998 three neutron access tubes were installed in each plot, to a depth of $2.0 \mathrm{~m}$, and readings were done immediately after a rain and on a weekly basis using a calibrated neutron probe. Neutron readings were used to calculate the cotton water use in each plot. For additional and specific details, the reader is referred to [9].

Cotton (Gossypium hirsutum L.) varieties planted, planting and emergence dates are given in Table 1 . The cotton varieties used in our experiments are considered to be moderately determinate, i.e., meaning that they set fruit early and is well adapted to the short-growing season of the THP. In the last two years of the experiment, 1998 and 1999, we used essentially the same variety as in previous years except that this variety was resistant to the glyphosate herbicide.

\subsection{Calculation of Heat Units}

To compare each of the growing seasons in terms of crop phenology we used and selected daily heat units (HU) and their cumulative value $\left(\sum \mathrm{HU}\right)$ over the

Table 1. Cotton variety planted, and dates of planting and emergence for the field experiment at Lubbock, TX from 1996 to 1999. The number in parenthesis after the calendar date is the corresponding Day Of Year (DOY).

\begin{tabular}{cccc}
\hline Year & Cotton Variety & Planting Date & Emergence Date \\
\hline 1996 & HS-26 & 7 May (127) & 13 May (134) \\
1997 & HS-26 & 19 May (139) & 1 June (152) \\
1998 & $2326-R^{\mathrm{b}}$ & 12 May (132) & 19 May (139) \\
1999 & $2326-\mathrm{RR}$ & 23 May (143) & 29 May (149) \\
\hline
\end{tabular}

a. Paymaster HS-26, Cargill Research, Plainview, TX; b. Roundup ${ }^{\circledR}$ Ready cotton Paymaster HS-26, Cargill Research, Plainview, TX. 
growing season. For cotton, a threshold air temperature of $15.6{ }^{\circ} \mathrm{C}$ was used to indicate the air temperature at which cotton ceases to grow [38]. The HU for a given day was calculated as follows:

$$
H C=\left(T_{\max }+T_{\min }\right) / 2-T_{t}
$$

where $\mathrm{T}_{\max }$ is the daily maximum air temperature $\left({ }^{\circ} \mathrm{C}\right), \mathrm{T}_{\min }$ is the daily minimum air temperature $\left({ }^{\circ} \mathrm{C}\right)$, and $\mathrm{T}_{\mathrm{t}}$ is the threshold temperature for cotton, i.e., $15.6{ }^{\circ} \mathrm{C}$. Air temperature was measured at a screen height of $2 \mathrm{~m}$ using a sensor (Model HMP-45C-L Vaisala Inc., Woburn, MA) on a weather station located in the center of the experimental field.

The duration of the cotton-growing season in the THP, from May to October, is relatively short. During planting, the cotton seedlings are subject to air temperatures below freezing and to thunderstorms with high wind speeds that cause plant damage [43]. Similarly, towards the end of the growing season at harvest, the weather may be cold and wet, causing cotton boll shedding and increasing the amount of trash in the harvested lint. We selected three values of $\Sigma \mathrm{HU}$ calculated as the sum of daily $\mathrm{HU}$ obtained with Equation (1) from the date cotton seedlings had emerged. These values were $890-{ }^{\circ} \mathrm{C} \Sigma \mathrm{HU}, 1000-{ }^{\circ} \mathrm{C} \Sigma \mathrm{HU}$, and $1110-{ }^{\circ} \mathrm{C} \Sigma \mathrm{HU}$. Hereafter, these values are referred to as early, intermediate and late irrigation termination thermal times.

\subsection{Fiber Quality and Lint Yield}

In our evaluation of the irrigation termination thermal time and level of irrigation it was of interest to determine the effect not only on the cotton lint yield but also on the quality of the harvested fiber. In general terms the physical attributes that are used to classify the properties of the raw cotton is referred to as "cotton classification" and this includes fiber length, micronaire, fiber strength and length uniformity [44]. Fiber length refers to the average length of the longer half of the fibers and it is reported in units of inches. Micronaire is a measure of the fiber fineness and maturity and a value between 37 and 42 is considered to be premium in terms of market value. Fiber strength is reported in grams per tex, where tex is equivalent to the mass in grams of $1 \mathrm{~km}$ of fiber length. A value of $\leq 23$ grams/tex is considered weak and a value of $\geq 31$ grams/tex is considered very strong. The fourth fiber property was length uniformity defined as the ratio in percent of the average fiber length to the upper-half mean length of the fibers. A ratio of $100 \%$ length uniformity signifies that all the fibers in a cotton bale are of the same length. A value of $>85 \%$ length uniformity is classified as "very high" and at the opposite end a value of $<77 \%$ is classified as "very low".

About $3 \mathrm{~m}$ of the middle row of each plot was hand-harvested and ginned at the facilities of the Texas A\&M AgriLife Research and Extension Center in Lubbock, TX. These samples were used to calculate cotton lint yield in $\mathrm{kg} / \mathrm{ha}$ for each plot and cotton samples from each plot were sent to the Fiber and Biopolymer Research Institute of the Department of Soil Science, Texas Tech University, Lubbock, TX, for the determination of fiber length, micronaire, fiber strength 
and length uniformity.

\section{Results and Discussion}

\subsection{Annual and Cumulative Rain and Heat Units}

The objective of this field experiment was to determine an optimal heat unit accumulation to end the irrigation of cotton with LEPA in the THP. For this purpose, we selected three termination thermal times of irrigation all based on cumulative daily heat units $(\mathrm{SHU})$ from the date cotton seedlings had emerged after planting. The three termination thermal times were early $\left(890^{\circ} \mathrm{C}\right)$, intermediate $\left(1000^{\circ} \mathrm{C}\right)$ and late $\left(1110^{\circ} \mathrm{C}\right)$. A summary of the length, from emergence to day of first freeze, of each of the four growing seasons, from 1996 to 1999, and the time needed to reach each $\Sigma \mathrm{HU}$ is given in Table 2. The shortest growing season was 1999 with 141 days and the longest growing season was 1998 with 175 days. The numbers of days required to reach the three-irrigation termination thermal times varied by year. For example, in 1998 only 71 days were required to reach the early irrigation termination thermal time, i.e., at a rate of $12.5^{\circ} \mathrm{C} /$ day and the previous year, 1997, it required an additional 24 days, at a rate of $9.4^{\circ} \mathrm{C} /$ day to achieve the same level. In 1996, the average rate of daily HU accumulation was $10.2{ }^{\circ} \mathrm{C} \pm 0.3{ }^{\circ} \mathrm{C} /$ day, in 1997 the rate was $9.2{ }^{\circ} \mathrm{C} \pm 0.2{ }^{\circ} \mathrm{C} /$ day, in 1998 the rate was $12.2{ }^{\circ} \mathrm{C} \pm 0.4{ }^{\circ} \mathrm{C} /$ day and in 1999 the rate was $10.8^{\circ} \mathrm{C} \pm 0.1{ }^{\circ} \mathrm{C} /$ day.

The monthly rainfall for each of the four years, 1996 to 1999, is shown in Figure 1 and the annual rain and $\Sigma \mathrm{HU}$ for the growing season is given in Figure 2. The annual rainfall was $379 \mathrm{~mm}$ in 1996, $515 \mathrm{~mm}$ in 1997, $267 \mathrm{~mm}$ in 1998 and $514 \mathrm{~mm}$ in 1999 (Figure 2). Two years, 1997 and 1999, had similar annual rain amounts, of $515 \mathrm{~mm}$. However, in 1997 rain in the month of April was $147 \mathrm{~mm}$, i.e., $29 \%$ of the total annual rain and in 1999 the monthly distribution was more even throughout the growing season. Year 1998 was dry, with only $267 \mathrm{~mm}$ and the August $(94 \mathrm{~mm}$ ) rain represented $35 \%$ of the yearly total. As expected the

Table 2. Length of the growing season, from emergence to first freeze, and days from emergence to reach each of the three cumulative daily heat units $(\Sigma \mathrm{HU})$ of $890{ }^{\circ} \mathrm{C}$ (early), $1000{ }^{\circ} \mathrm{C}$ (intermediate) and $1110{ }^{\circ} \mathrm{C}$ (late) for each year when irrigation was terminated, from 1996 to 1999 . Also given is the average rate $\left({ }^{\circ} \mathrm{C} /\right.$ day $) \pm \mathrm{SD}$ to reach each $\Sigma \mathrm{HU}$, where SD is the standard deviation.

\begin{tabular}{cccccc}
\hline Year & $\begin{array}{c}\text { Growing } \\
\text { Season (days) }\end{array}$ & $\begin{array}{c}\text { Planting to } \\
890{ }^{\circ} \mathrm{C}-\text { Early } \\
\text { (days) }\end{array}$ & $\begin{array}{c}\text { Planting to } 1000 \\
{ }^{\circ} \text { C-Intermediate } \\
\text { (days) }\end{array}$ & $\begin{array}{c}\text { Planting to } 1110 \\
{ }^{\circ} \mathrm{C}-\text { Late } \\
\text { (days) }\end{array}$ & $\begin{array}{c}\text { Average } \\
\left({ }^{\circ} \mathrm{C} / \text { day) } \pm \mathrm{SD}\right.\end{array}$ \\
\hline 1996 & 161 & 85 & 97 & 112 & $10.2 \pm 0.3$ \\
1997 & 146 & 95 & 107 & 123 & $9.2 \pm 0.2$ \\
1998 & 175 & 71 & 81 & 94 & $12.2 \pm 0.4$ \\
1999 & 141 & 83 & 92 & 104 & $10.8 \pm 0.1$ \\
Average & 156 & 84 & 94 & 108 & \\
SD & 15 & 10 & 11 & 12 & \\
\hline
\end{tabular}




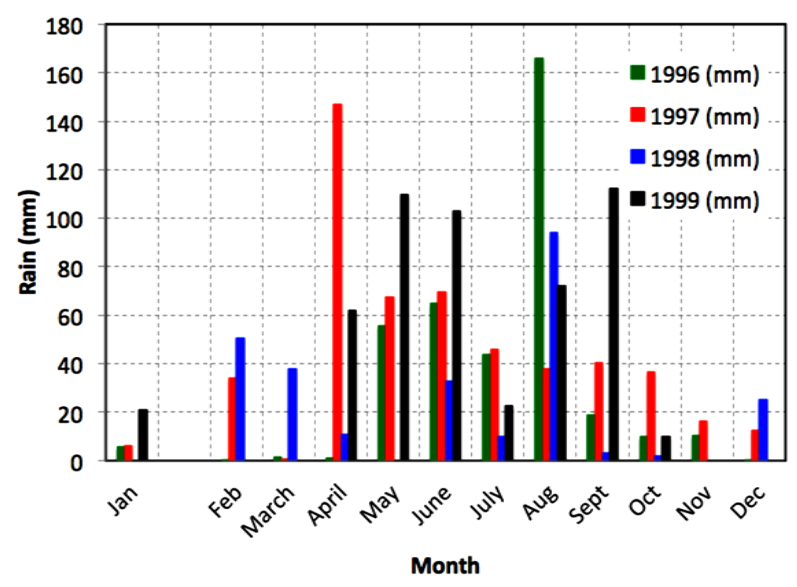

Figure 1. Monthly rainfall distribution, 1996-1999, measured at the experimental field, Lubbock, TX. Each year is indicated by a different color, i.e., 1996, 1997, 1998, and 1999.

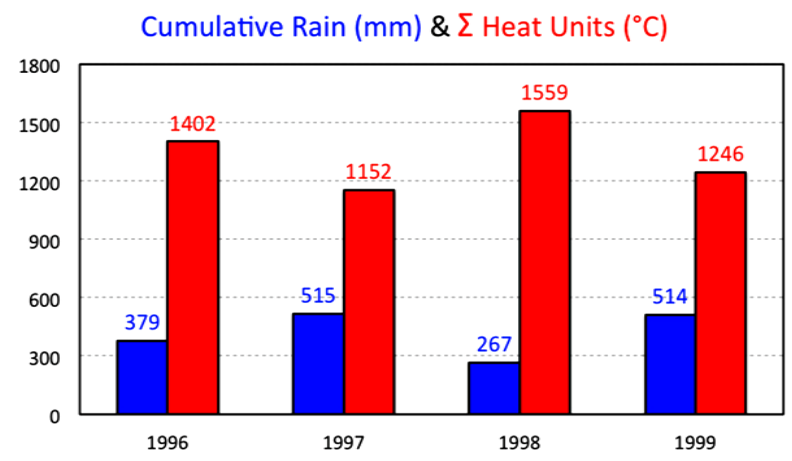

Figure 2. Annual rain ( $\mathrm{mm})$ and $\sum$ daily heat units $\left({ }^{\circ} \mathrm{C}\right)$ over the length of the growing seasons, 1996-1999, measured at the experimental field, Lubbock, TX.

rate of daily $\mathrm{HU}$ accumulation is related to cooler and wetter weather, e.g., 1997 was the wettest year with $515 \mathrm{~mm}$ of rain, particularly in the month of April with $147 \mathrm{~mm}$ of rain (Figure 1).

The monthly $\Sigma \mathrm{HU}$ for each of the growing seasons, 1996-1999, is given in Figure 3 and the corresponding cumulative amount is given in Figure 2. Each year was different and the year, 1998 , with most $\Sigma \mathrm{HU}$ of $1559{ }^{\circ} \mathrm{C}$ was also the driest year with only $267 \mathrm{~mm}$ of rain (Figure 2).

\subsection{Irrigation Applied and Water Use}

Irrigation-water applied for the low, medium and high irrigation level and for the three termination thermal times for each of the four years of the experiment is given in Table 3. The amount of irrigation water applied varied considerably by treatment and by year. For example, the least amount of irrigation-water applied was $79 \mathrm{~mm}$ for the low irrigation level $(2.5 \mathrm{~mm} / \mathrm{d})$ and the early termination thermal time $(\Sigma \mathrm{HU})$ of $890^{\circ} \mathrm{C}$ in 1996 and for the high irrigation level $(7.6$ $\mathrm{mm} / \mathrm{d}$ ) on the intermediate termination thermal time $(\Sigma \mathrm{HU})$ of $1000^{\circ} \mathrm{C}$ the same 


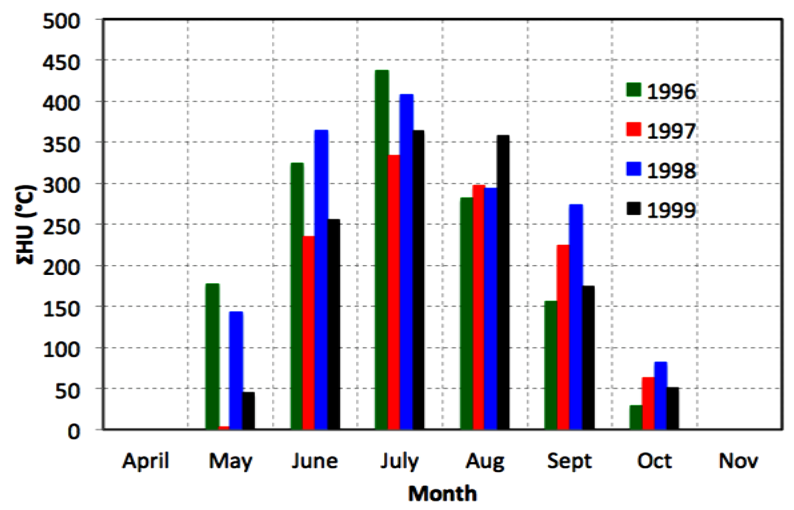

Figure 3. Monthly cumulative daily heat units $\left(\sum \mathrm{HU}^{\circ} \mathrm{C}\right)$ over the length of the growing season for each of the four years, 1996-1999, at the experimental field, Lubbock, TX. Each year is indicated by a different color, i.e., 1996, 1997, 1998, and 1999.

Table 3. Amount of irrigation-water applied $(\mathrm{mm})$ for the three irrigation levels (low, medium and high) and for the three irrigation termination $\Sigma \mathrm{HU}$ dates (early, intermediate, and late) in each of the four years (1996-1999) of the field experiment, Lubbock, TX.

\begin{tabular}{cccccc}
\hline $\begin{array}{c}\text { Irrigation Level } \\
(\mathrm{mm} / \mathrm{d})\end{array}$ & $\begin{array}{c}\text { Termination Thermal } \\
\text { Time } \Sigma \text { HU }\left({ }^{\circ} \mathrm{C}\right)\end{array}$ & $1996(\mathrm{~mm})$ & $1997(\mathrm{~mm})$ & $1998(\mathrm{~mm})$ & $1999(\mathrm{~mm})$ \\
\hline $\begin{array}{c}\text { Low } \\
(2.5)\end{array}$ & Early $(890)$ & 79 & 69 & 84 & 84 \\
& Intermediate $(1000)$ & 112 & 91 & 84 & 99 \\
& Late (1110) & 135 & 114 & 107 & 130 \\
Medium & Early (890) & 102 & 137 & 152 & 165 \\
$(5.1)$ & Intermediate (1000) & 173 & 183 & 175 & 196 \\
& Late (1110) & 218 & 226 & 208 & 257 \\
High & Early (890) & 165 & 170 & 254 & 216 \\
$(7.6)$ & Intermediate (1000) & 79 & 226 & 272 & 257 \\
& Late (1110) & 267 & 284 & 305 & 325 \\
\hline
\end{tabular}

year. On the opposite end, the most irrigation-water applied was $325 \mathrm{~mm}$ in 1999 for the high irrigation level $(7.6 \mathrm{~mm} / \mathrm{d})$ and the late termination time $(\Sigma \mathrm{HU})$ of $1110{ }^{\circ} \mathrm{C}$. On average the low irrigation level $(2.5 \mathrm{~mm} / \mathrm{d})$ treatment received about $60 \%$ of the water applied to the high level and the medium level $(5.6 \mathrm{~mm} / \mathrm{d})$ received about $80 \%$ of water applied to the high irrigation level. All irrigation-water was applied on a 3-d frequency. In the THP, the amount of irrigation-water that can be applied is an important parameter in the irrigation management of the crop, as it is dictated by the well capacity and it thus determines the scheduling of irrigation [9].

The seasonal water use, as measured with the neutron meter, for each of the three-irrigation levels from 1996 to 1998 is given in Table 4. In 1999, the neu- 
tron meter malfunctioned and we were able to measure soil water content. These values represent the average across all treatments and as expected the crop water use increases as the amount of irrigation-water applied increases. These seasonal values of water use are typical for the environment of the THP [13] [45] [46].

\subsection{Lint Yield}

The measured cotton lint yield for the low, medium and high irrigation level and for the three irrigation termination thermal times in the four-year period from 1996 to 1999, in Lubbock TX are given in Table 5. Across four years the mean cotton lint yield was highest for the high irrigation level $(7.6 \mathrm{~mm} / \mathrm{d})$. For the highest irrigation level $(7.6 \mathrm{~mm} / \mathrm{d})$ results showed that terminating at the early (890 $\Sigma \mathrm{HU})$ date resulted in statistically the highest lint yield. Terminating irrigation when the $\Sigma \mathrm{HU}$ reached $1000{ }^{\circ} \mathrm{C}$ translates into a savings of 25 to $50 \mathrm{~mm}$ of irrigation-water for the low and medium irrigation level. Similarly, terminating.

Table 4. Average seasonal water use $(\mathrm{mm})$ for the three irrigation levels from 1996 to 1998. Means within years followed by the same letter are not significantly different, $\mathrm{P}<$ 0.05 , according to the least significant difference.

\begin{tabular}{cccc}
\hline Year & \multicolumn{3}{c}{ Seasonal Water Use (mm) } \\
\hline $\begin{array}{c}2.5 \mathrm{~mm} / \mathrm{d} \\
(\text { Low })\end{array}$ & $\begin{array}{c}5.1 \mathrm{~mm} / \mathrm{d} \\
(\text { Medium })\end{array}$ & $\begin{array}{c}7.6 \mathrm{~mm} / \mathrm{d} \\
(\text { High })\end{array}$ \\
\hline 1996 & $465 \mathrm{c}$ & $521 \mathrm{~b}$ & $566 \mathrm{a}$ \\
1997 & $290 \mathrm{~b}$ & $391 \mathrm{a}$ & $434 \mathrm{a}$ \\
1998 & $249 \mathrm{~b}$ & $384 \mathrm{a}$ & $470 \mathrm{a}$ \\
\hline
\end{tabular}

Table 5. Cotton lint yield for the low, medium and high irrigation level and for the three irrigation termination thermal times for the four year period, 1996-1999, at Lubbock, TX. Means within years followed by the same letter are not significantly different, $\mathrm{P}<0.05$, according to the least significant difference.

\begin{tabular}{|c|c|c|c|c|c|}
\hline \multirow[b]{2}{*}{$\begin{array}{l}\text { Irrigation Level } \\
\qquad(\mathrm{mm} / \mathrm{d})\end{array}$} & \multirow[b]{2}{*}{$\begin{array}{c}\text { Termination Thermal Time } \\
\sum \mathrm{HU}\left({ }^{\circ} \mathrm{C}\right)\end{array}$} & \multicolumn{4}{|c|}{ Cotton Lint Yield (kg/ha) } \\
\hline & & 1996 & 1997 & 1998 & 1999 \\
\hline \multirow{3}{*}{$\begin{array}{l}\text { Low } \\
(2.5)\end{array}$} & Early (890) & $930 \mathrm{c}$ & $731 \mathrm{~b}$ & 821 e & $737 \mathrm{ab}$ \\
\hline & Intermediate (1000) & $1140 \mathrm{ab}$ & $830 \mathrm{ab}$ & $810 \mathrm{e}$ & $558 \mathrm{~b}$ \\
\hline & Late $(1110)$ & $1092 \mathrm{~b}$ & $812 \mathrm{ab}$ & 889 de & $799 \mathrm{ab}$ \\
\hline \multirow{3}{*}{$\begin{array}{l}\text { Medium } \\
\quad(5.1)\end{array}$} & Early (890) & $1076 \mathrm{bc}$ & $874 \mathrm{ab}$ & $936 \mathrm{~cd}$ & $764 \mathrm{ab}$ \\
\hline & Intermediate (1000) & $1181 \mathrm{ab}$ & $954 \mathrm{a}$ & $1014 \mathrm{bc}$ & $875 a b$ \\
\hline & Late (1110) & 1269 a & 928 a & $1138 \mathrm{a}$ & $774 \mathrm{ab}$ \\
\hline \multirow{3}{*}{$\begin{array}{l}\text { High } \\
(7.6)\end{array}$} & Early (890) & $1167 \mathrm{ab}$ & $843 \mathrm{ab}$ & $985 \mathrm{~cd}$ & $1051 \mathrm{a}$ \\
\hline & Intermediate (1000) & $1174 \mathrm{ab}$ & $954 \mathrm{a}$ & $51 \mathrm{bc}$ & $801 \mathrm{ab}$ \\
\hline & Late (1110) & $1228 \mathrm{ab}$ & $954 \mathrm{a}$ & $1123 \mathrm{ab}$ & $981 \mathrm{~b}$ \\
\hline
\end{tabular}


irrigation for the high level $(7.6 \mathrm{~mm} / \mathrm{d})$ of irrigation when the $\Sigma \mathrm{HU}$ reached the early termination thermal time of $890{ }^{\circ} \mathrm{C}$ would have saved between 100 to 115 $\mathrm{mm}$ of irrigation-water, without a lint yield penalty (Table 5)

To further evaluate the optimal termination thermal time of irrigation on cotton lint yield we averaged the lint yield for the three levels of irrigation and these results are given in Table 6. In all years, except 1998 the intermediate irrigation termination thermal time of $\Sigma \mathrm{HU}$ of $1000{ }^{\circ} \mathrm{C}$ resulted in the largest mean lint yield of $1165 \mathrm{~kg} / \mathrm{ha}$ in 1996, lint yield of $913 \mathrm{~kg} / \mathrm{ha}$ in 1997 and $744 \mathrm{~kg} / \mathrm{ha}$ in 1999 , though these differences were not always statistically significant at the $\mathrm{P}$ $=0.05$ level. In the remaining year, 1998 the late irrigation termination thermal time of $1110{ }^{\circ} \mathrm{C}$, which was the driest year with $267 \mathrm{~mm}$ of rain (Figure 2) statistically yielded the largest cotton lint yield of $1050 \mathrm{~kg} / \mathrm{ha}$. Nevertheless, across the four-year period, the intermediate irrigation termination thermal time of 1000 ${ }^{\circ} \mathrm{C}$ resulted in lint yield value of $943 \mathrm{~kg} / \mathrm{ha}$ and represents irrigation savings of 25 to $100 \mathrm{~mm}$ of water. This is a considerable water savings; however, in cotton it is not only the amount of fiber produced that needs to be considered as the fiber quality and its market value increasingly impacts the profits of cotton producers in the THP. The decision of when to stop irrigating cotton is affected by the rate of daily $\mathrm{HU}$ accumulation and by the amount of rainfall received during the growing season.

Another important aspect of irrigation water management is related to the amount of lint produced per unit of water used by the crop (Table 7). These results show that the irrigation level of $2.5 \mathrm{~mm} / \mathrm{d}$ resulted in statistically the largest value of $1133 \pm 27 \mathrm{~g} / \mathrm{ha} \mathrm{mm}$, and conversely the high irrigation level of $7.5 \mathrm{~mm} / \mathrm{d}$ resulted in the lowest value, $869 \pm 26 \mathrm{~g} / \mathrm{ha} \mathrm{mm}$. In relative terms, on average, the medium irrigation level produced $13 \%$ less cotton per $\mathrm{mm}$ of water and the high irrigation produced $23 \%$ less cotton per $\mathrm{mm}$ of water compared to the low irrigation level of $2.5 \mathrm{~mm} / \mathrm{d}$.

\subsection{Lint Quality}

Four fiber properties, i.e., fiber length, micronaire, fiber length uniformity and fiber strength were selected to quantify the effect of termination thermal time of irrigation on the quality of cotton lint. These results are shown in Table 8.

Table 6. Cotton lint yield averaged across the three irrigation levels and for each of the three termination thermal times for the four year period, 1996-1999, at Lubbock, TX. Means within years followed by the same letter are not significantly different, $\mathrm{P}<0.05$, according to the least significant difference.

\begin{tabular}{cccccc}
\hline & \multicolumn{4}{c}{ Average Cotton Lint Yield (kg/ha) } & $\begin{array}{c}\text { Four Year } \\
\text { Average } \\
(\mathrm{kg} / \mathrm{ha})\end{array}$ \\
\hline $\begin{array}{c}\text { Termination } \\
\sum H \mathrm{HU}\left({ }^{\circ} \mathrm{C}\right)\end{array}$ & 1996 & 1997 & 1998 & 1999 & $910 \mathrm{~b}$ \\
\hline Low $(890)$ & $1058 \mathrm{~b}$ & $816 \mathrm{~b}$ & $914 \mathrm{~b}$ & $851 \mathrm{a}$ & $943 \mathrm{~b}$ \\
Medium $(1000)$ & $1165 \mathrm{a}$ & $913 \mathrm{a}$ & $947 \mathrm{~b}$ & $744 \mathrm{a}$ & $999 \mathrm{a}$ \\
High $(1110)$ & $1196 \mathrm{a}$ & $898 \mathrm{a}$ & $1050 \mathrm{a}$ & $851 \mathrm{a}$ & \\
\hline
\end{tabular}


Table 7. Lint yield per seasonal water use for the three irrigation levels, from 1996 to 1998, at Lubbock, TX. Means within years followed by the same letter are not significantly different, $\mathrm{P}<0.05$, according to the least significant difference.

\begin{tabular}{cccc}
\hline Year & \multicolumn{3}{c}{ Lint Yield/Water Use (g/ha mm) } \\
\hline & $2.5 \mathrm{~mm} / \mathrm{d}$ (Low) & $5.1 \mathrm{~mm} / \mathrm{d}$ (Medium) & $7.6 \mathrm{~mm} / \mathrm{d}$ (High) \\
\hline 1996 & $918 \mathrm{a}$ & $916 \mathrm{a}$ & $849 \mathrm{~b}$ \\
1997 & $1110 \mathrm{a}$ & $949 \mathrm{ab}$ & $859 \mathrm{~b}$ \\
1998 & $1371 \mathrm{a}$ & $1084 \mathrm{ab}$ & $899 \mathrm{~b}$ \\
\hline
\end{tabular}

Table 8. Cotton fiber length, micronaire, fiber length uniformity and fiber strength averaged for the three irrigation levels and for the early, intermediate and late irrigation termination thermal times for the four year period, 1996-1999, at Lubbock, TX. Also given is the four year average for each fiber property. Means within years followed by the same letter are not significantly different, $\mathrm{P}<0.05$, according to the least significant difference.

\begin{tabular}{|c|c|c|c|}
\hline \multirow{2}{*}{ Year } & \multicolumn{3}{|c|}{ Average Fiber Length (inches) } \\
\hline & $\Sigma \mathrm{HU} 890^{\circ} \mathrm{C}$ (Early) & $\Sigma \mathrm{HU} 1000{ }^{\circ} \mathrm{C}$ (Intermediate) & $\Sigma \mathrm{HU} 1110^{\circ} \mathrm{C}$ (Late) \\
\hline 1996 & $1.069 \mathrm{~b}$ & $1.083 \mathrm{a}$ & $1.084 \mathrm{a}$ \\
\hline 1997 & $1.073 \mathrm{a}$ & $1.080 \mathrm{a}$ & $1.076 \mathrm{a}$ \\
\hline 1998 & $1.066 \mathrm{~b}$ & $1.073 \mathrm{ab}$ & $1.077 \mathrm{a}$ \\
\hline 1999 & $1.048 \mathrm{a}$ & $1.040 \mathrm{a}$ & $1.056 \mathrm{a}$ \\
\hline Average & $1.064 \mathrm{~b}$ & $1.069 \mathrm{ab}$ & $1.073 \mathrm{a}$ \\
\hline \multirow{2}{*}{ Year } & \multicolumn{3}{|c|}{ Average Micronaire } \\
\hline & $\Sigma \mathrm{HU} 890^{\circ} \mathrm{C}$ (Early) & $\Sigma \mathrm{HU} 1000^{\circ} \mathrm{C}$ (Intermediate) & $\Sigma \mathrm{HU} 1110^{\circ} \mathrm{C}$ (Late) \\
\hline 1996 & $4.642 \mathrm{a}$ & $4.615 \mathrm{a}$ & $4.567 \mathrm{a}$ \\
\hline 1997 & $4.538 \mathrm{c}$ & $4.811 \mathrm{~b}$ & $4.963 \mathrm{a}$ \\
\hline 1998 & $4.198 \mathrm{a}$ & $4.230 \mathrm{a}$ & $4.197 \mathrm{a}$ \\
\hline 1999 & $4.842 \mathrm{a}$ & $4.708 \mathrm{a}$ & $4.967 \mathrm{a}$ \\
\hline Average & $4.558 \mathrm{~b}$ & $4.592 \mathrm{~b}$ & $4.675 \mathrm{a}$ \\
\hline \multirow{2}{*}{ Year } & \multicolumn{3}{|c|}{ Average Fiber Length Uniformity (\%) } \\
\hline & $\Sigma \mathrm{HU} 890^{\circ} \mathrm{C}$ (Early) & $\Sigma \mathrm{HU} 1000{ }^{\circ} \mathrm{C}$ (Intermediate) & $\sum \mathrm{HU} 1110^{\circ} \mathrm{C}$ (Late) \\
\hline 1996 & $82.083 \mathrm{a}$ & $82.292 \mathrm{a}$ & $82.396 \mathrm{a}$ \\
\hline 1997 & $83.035 \mathrm{~b}$ & $83.508 \mathrm{a}$ & $83.400 \mathrm{a}$ \\
\hline 1998 & $81.358 \mathrm{~b}$ & $81.767 \mathrm{a}$ & $81.753 \mathrm{a}$ \\
\hline 1999 & $83.153 \mathrm{a}$ & $83.208 \mathrm{a}$ & $83.650 \mathrm{a}$ \\
\hline Average & $82.408 \mathrm{~b}$ & $82.694 \mathrm{~b}$ & $82.800 \mathrm{a}$ \\
\hline \multirow{2}{*}{ Year } & \multicolumn{3}{|c|}{ Average Fiber Strength (grams/tex) } \\
\hline & $\Sigma$ HU $890^{\circ} \mathrm{C}$ (Early) & $\sum \mathrm{HU} 1000^{\circ} \mathrm{C}$ (Intermediate) & $\sum \mathrm{HU} 1110^{\circ} \mathrm{C}$ (Late) \\
\hline 1996 & 30.979 a & $30.167 \mathrm{~b}$ & $30.063 \mathrm{~b}$ \\
\hline 1997 & $31.004 \mathrm{a}$ & $30.310 \mathrm{~b}$ & $30.638 \mathrm{ab}$ \\
\hline 1998 & $28.833 \mathrm{ab}$ & $29.193 \mathrm{a}$ & $28.786 \mathrm{~b}$ \\
\hline 1999 & $29.108 \mathrm{a}$ & $28.708 \mathrm{a}$ & $28.517 \mathrm{a}$ \\
\hline Average & $30.175 \mathrm{a}$ & $29.767 \mathrm{~b}$ & $29.673 \mathrm{~b}$ \\
\hline
\end{tabular}


These values are the average across the three irrigation levels. These parameters are used to classify the properties of the harvested cotton fiber and determine the market value of the cotton lint. These results show that the three irrigation termination thermal times affected the fiber length in 1996 and 1998and there was no effect in 1997 and 1998. These results suggest that for a growing season that is both hot and dry the fiber length is reduced by an early irrigation termination thermal time. These two years were the driest in terms of rain and the hottest in terms of $\Sigma H U$ over the growing season (Figure 2). In 1996, 1998 and 1999 there was no effect of the irrigation termination thermal time on micronaire; however, in 1997 micronaire statistically increased with the irrigation termination thermal time. The 1997-year was characterized by above average rain $(515 \mathrm{~mm})$ and low $\Sigma \mathrm{HU}$ of $1,152{ }^{\circ} \mathrm{C}$ (Figure 2). The irrigation termination thermal time statistically affected the average fiber length uniformity only in 1997 and 1998 for the early irrigation termination thermal time of $890{ }^{\circ} \mathrm{C}$. The average fiber strength was affected in all years except 1999 and on average the early irrigation termination of $890{ }^{\circ} \mathrm{C}$ had an average fiber strength of 30.175 grams/tex, which was higher than for the intermediate and late irrigation termination thermal times. These results suggest that for the environmental conditions of the THP, an early termination thermal time of irrigation saves water and on average has a lower fiber strength, micronaire, fiber length uniformity and fiber strength. However, the impact of these environmental conditions on the economic value of a unit mass of lint was not statistically significant (values not shown).

The cotton fiber properties averaged across the three irrigation termination thermal times and as a function of the three irrigation levels are given in Table 9. On average, the fiber length increased from 1.055 inches to 1.081 inches with irrigation level, the average micronaire was largest for the low level, and the average fiber strength was lowest for the high irrigation level. The irrigation level did not affect the average fiber length uniformity.

In the textile industry fiber length, is traditionally reported in inches, and is a property that is largely influenced by variety. Nevertheless, environmental conditions such as extreme air temperature, nutrient and water stress may result in shorter fibers [47] [48] [49] [50]. In general, the early $890-{ }^{\circ} \mathrm{C} \Sigma \mathrm{HU}$ irrigation termination thermal time resulted in the shortest fibers; an average of 1.064 inches and the late $1110-^{\circ} \mathrm{C} \Sigma \mathrm{HU}$ resulted in the longest fibers, an average of 1.073 inches (Table 8). A similar pattern was observed for the effect of the irrigation level and the average length increased from 1.055 inches for the low (2.5 $\mathrm{mm} / \mathrm{d}$ ) irrigation to 1.081 inches for the high $(7.6 \mathrm{~mm} / \mathrm{d}$ ) irrigation (Table 9). However, based on the market value (data not shown) this difference did not represent a significant economic benefit.

Micronaire is a measure of fiber maturity and can be influenced by the environmental conditions during the growing season [51] [52]. Our results showed that micronaire was only statistically affected by the irrigation termination thermal time in 1997 (Table 8) a wet and cool year (Figure 2). In general, the 
Table 9. Cotton fiber length, micronaire, fiber length uniformity and fiber strength averaged for the three irrigation thermal times and for the low, medium and high irrigation level for the four year period, 1996-1999, at Lubbock, TX. Also given is the four year average for each fiber property. Means within years followed by the same letter are not significantly different, $\mathrm{P}<0.05$, according to the least significant difference.

\begin{tabular}{|c|c|c|c|}
\hline \multirow{2}{*}{ Year } & \multicolumn{3}{|c|}{$\begin{array}{l}\text { Average Fiber Length } \\
\text { (inches) }\end{array}$} \\
\hline & $\begin{array}{l}2.5 \mathrm{~mm} / \mathrm{d} \\
\text { (Low) }\end{array}$ & $\begin{array}{l}5.1 \mathrm{~mm} / \mathrm{d} \\
\text { (Medium) }\end{array}$ & $\begin{array}{c}7.6 \mathrm{~mm} / \mathrm{d} \\
\text { (High) }\end{array}$ \\
\hline 1996 & $1.069 \mathrm{~b}$ & $1.085 \mathrm{a}$ & $1.082 \mathrm{ab}$ \\
\hline 1997 & $1.056 \mathrm{c}$ & $1.078 \mathrm{~b}$ & $1.096 \mathrm{a}$ \\
\hline 1998 & $1.057 \mathrm{~b}$ & $1.073 \mathrm{ab}$ & $1.086 \mathrm{a}$ \\
\hline 1999 & $1.036 \mathrm{a}$ & $1.046 \mathrm{a}$ & $1.056 \mathrm{a}$ \\
\hline Average & $1.055 \mathrm{c}$ & $1.070 \mathrm{~b}$ & $1.081 \mathrm{a}$ \\
\hline \multirow[b]{2}{*}{ Year } & \multicolumn{3}{|c|}{ Average Micronaire } \\
\hline & $\begin{array}{c}2.5 \mathrm{~mm} / \mathrm{d} \\
(\text { Low })\end{array}$ & $\begin{array}{l}5.1 \mathrm{~mm} / \mathrm{d} \\
(\text { Medium })\end{array}$ & $\begin{array}{c}7.6 \mathrm{~mm} / \mathrm{d} \\
\text { (High) }\end{array}$ \\
\hline 1996 & $4.804 \mathrm{a}$ & $4.590 \mathrm{~b}$ & $4.429 c$ \\
\hline 1997 & $4.792 \mathrm{a}$ & $4.799 \mathrm{a}$ & $4.721 \mathrm{a}$ \\
\hline 1998 & $4.525 \mathrm{a}$ & $4.119 \mathrm{a}$ & $3.982 \mathrm{a}$ \\
\hline 1999 & $4.817 \mathrm{a}$ & $4.875 \mathrm{a}$ & $4.825 \mathrm{a}$ \\
\hline Average & $4.732 \mathrm{a}$ & $4.598 \mathrm{~b}$ & $4.494 \mathrm{~b}$ \\
\hline \multirow{2}{*}{ Year } & \multicolumn{3}{|c|}{$\begin{array}{c}\text { Average Fiber Length Uniformity } \\
(\%)\end{array}$} \\
\hline & $\begin{array}{l}2.5 \mathrm{~mm} / \mathrm{d} \\
\text { (Low) }\end{array}$ & $\begin{array}{l}5.1 \mathrm{~mm} / \mathrm{d} \\
\text { (Medium) }\end{array}$ & $\begin{array}{c}7.6 \mathrm{~mm} / \mathrm{d} \\
\text { (High) }\end{array}$ \\
\hline 1996 & $82.333 \mathrm{ab}$ & $82.667 \mathrm{a}$ & $81.771 \mathrm{~b}$ \\
\hline 1997 & $82.794 \mathrm{~b}$ & $83.400 \mathrm{a}$ & $83.750 \mathrm{a}$ \\
\hline 1998 & $81.908 \mathrm{a}$ & $81.442 \mathrm{a}$ & $81.528 \mathrm{a}$ \\
\hline 1999 & 82.917 a & $83.453 \mathrm{a}$ & $83.642 \mathrm{a}$ \\
\hline Average & $82.488 \mathrm{a}$ & $82.740 \mathrm{a}$ & $82.673 \mathrm{a}$ \\
\hline \multirow{2}{*}{ Year } & \multicolumn{3}{|c|}{$\begin{array}{l}\text { Average Fiber Strength } \\
\text { (grams/tex) }\end{array}$} \\
\hline & $\begin{array}{c}2.5 \mathrm{~mm} / \mathrm{d} \\
(\text { Low })\end{array}$ & $\begin{array}{l}5.1 \mathrm{~mm} / \mathrm{d} \\
(\text { Medium })\end{array}$ & $\begin{array}{c}7.6 \mathrm{~mm} / \mathrm{d} \\
\text { (High) }\end{array}$ \\
\hline 1996 & $31.042 \mathrm{a}$ & $30.542 \mathrm{a}$ & $29.625 \mathrm{~b}$ \\
\hline 1997 & $30.842 \mathrm{c}$ & $30.575 \mathrm{~b}$ & $30.535 \mathrm{a}$ \\
\hline 1998 & $29.283 \mathrm{a}$ & 28.859 a & 28.671 a \\
\hline 1999 & $28.950 \mathrm{a}$ & $29.152 \mathrm{a}$ & $28.231 \mathrm{a}$ \\
\hline Average & $30.202 \mathrm{a}$ & $29.957 \mathrm{a}$ & $29.458 \mathrm{~b}$ \\
\hline
\end{tabular}

effect of irrigation level was that micronaire increased with an increasing level of irrigation (Table 9) but was only statistically significant for the low irrigation level of $2.5 \mathrm{~mm} / \mathrm{d}$. 
Fiber length uniformity is a property that affects yarn evenness and strength and is related to the efficiency of the spinning process. For example, cotton with a low uniformity is normally associated with cotton with short fibers. The results show that the irrigation termination thermal time (Table 8) had a minimal effect on fiber length for the early termination thermal time $\left(890^{\circ} \mathrm{C}\right)$ and the irrigation level (Table 9) had a similar effect; however, the average fiber length uniformity across the three irrigation values were $>82 \%$, which is an index that classifies the cotton as intermediate to high.

The fourth and final fiber property was fiber strength, which is a property that is largely determined by the cotton variety planted; however, there are some nutrient related deficiencies that affect this value [52] [53]. The results of fiber strength (grams/tex) analysis indicated that on average a slight effect of the early irrigation termination thermal time occurred (Table 8) with a value of 30.175 grams/tex compared to 29.673 grams/tex for the intermediate and late irrigation termination thermal time. The opposite effect was observed for the effect of the level of irrigation on fiber strength (Table 9). These values ranged on average from a low of 29.458 grams/tex for the high irrigation level to a high of 30.202 grams/tex for the low irrigation level, corresponding to a classification of strong to very strong fiber strength. Again the impact of this fiber property on the market value of the lint was not significant (data not shown).

\section{Summary and Conclusions}

As pointed out by [32], the decision as to when to terminate the irrigation on a cotton crop is a function of many variables that include lint yield and quality, the costs of irrigation and market value. For the environmental conditions of the THP, which is characterized by a short growing season subject to damaging weather at both planting [43] and harvest [9], an important determinant of when to stop irrigation is given by the well capacity. Therefore, we evaluated three irrigation termination thermal times, based on cumulative heat units for three levels of irrigation that spanned the range of well capacities used to irrigate in the THP.

The three termination thermal times of irrigation were $890{ }^{\circ} \mathrm{C}, 1000{ }^{\circ} \mathrm{C}$ and $1110{ }^{\circ} \mathrm{C}$, which are cumulative daily heat units from emergence and represent the heat unit availability across the THP [42]. The selected three well capacities delivered $2.5 \mathrm{~mm} / \mathrm{d}, 5.1 \mathrm{~mm} / \mathrm{d}$ and $7.6 \mathrm{~mm} / \mathrm{d}$ that represented the range of well capacities in the THP [9]. The results from this four-year field experiment showed that on average and as expected the high irrigation level $(7.6 \mathrm{~mm} / \mathrm{d})$ produced the most cotton lint yield regardless of when the irrigation termination thermal time ended. The largest cotton lint yield was achieved for the early termination thermal time of $890{ }^{\circ} \mathrm{C}$ when irrigated at the highest level of $7.6 \mathrm{~mm} / \mathrm{d}$ (Table 5). Terminating irrigation when the cumulative heat units reached 1000

${ }^{\circ} \mathrm{C}$, i.e., the intermediate date, resulted in water savings of 25 to $50 \mathrm{~mm}$ of water (Table 6) for the low $(2.5 \mathrm{~mm} / \mathrm{d})$ and medium $(5.1 \mathrm{~mm} / \mathrm{d})$ irrigation level. At 
the high irrigation water level $(7.6 \mathrm{~mm} / \mathrm{d})$ and terminating irrigation at the early date $\left(890^{\circ} \mathrm{C}\right)$ can result in water savings of 100 to $115 \mathrm{~mm}$.

The effect of the termination thermal time of irrigation affected some of the fiber properties (Table 8) and these are linked to the seasonal rain and daily values of heat units. For example, the irrigation termination thermal times affected fiber length in 1996 and 1998, the two years with the least rainfall and warmer air temperature. Also in the two years with more than $500 \mathrm{~mm}$ of rain the fiber micronaire tended to increase with the termination thermal time of irrigation. Fiber length was shortest for the early termination thermal time and fiber length uniformity was not affected by the irrigation termination thermal time. The only clear significant statistical effect of the irrigation level was on fiber length, i.e., it increased with increasing water level. The effect on micronaire was a decrease with increasing water level (Table 9). We conclude that based on these results and for the growing conditions of the THP the irrigation of cotton can be terminated when the cumulative heat units from planting reach about $1000{ }^{\circ} \mathrm{C}$. Our results showed that this practice can save between 50 to $100 \mathrm{~mm}$ of irrigation water for the range of wells that are common in the THP.

\section{Declaration}

Mention of trade names or commercial products in this publication is solely for the purpose of providing specific information and does not imply recommendation or endorsement by the U.S. Department of Agriculture. The USDA is an equal opportunity provider and employer.

\section{References}

[1] Arneson, E.P. (1921) Early Irrigation in Texas. Southwestern Historical Quarterly, 25, 121-130.

[2] Bloodworth, M.E. and Gillett, P.T. (1984) IRRIGATION-Handbook of Texas Online. Texas State Historical Association, Austin. http://www.tshaonline.org/handbook/online/articles/ahi01

[3] Musick, J.T., Pringle, F.B., Harman, W.L. and Stewart, B.A. (1990) Long-Term Irrigation Trends-Texas High Plains. Applied Engineering in Agriculture, 6, 717-724. https://doi.org/10.13031/2013.26454

[4] Colaizzi, P.D., Gowda, P.H., Marek, T.H. and Porter, D.O. (2009) Irrigation in the Texas High Plains: A Brief History and Potential Reductions in Demand. Irrigation and Drainage, 58, Article ID: 257274. https://doi.org/10.1002/ird.418

[5] Green, D.E. (1973) Land of the Underground Rain: Irrigation on the Texas High Plains, 1910-1970. University of Texas Press, Austin, 326 p.

[6] Musick, J.T. Pringle, F.B. and Walker, J.D. (1988) Sprinkler and Furrow Irrigation Trends: Texas High Plains. Applied Engineering in Agriculture, 4, 46-52. https://doi.org/10.13031/2013.26578

[7] Opie, J. (2000) Ogallala: Water for a Dry Land. 2nd Edition, University of Nebraska Press, Lincoln, $475 \mathrm{p}$.

[8] Scanlon, B.R., Faunt, C.C., Longuevergne, L., Reedy, R.C., Alley, W.M., McGuire, V.L. and McMahon, P.B. (2012) Groundwater Depletion and Sustainability of Irri- 
gation in the US High Plains and Central Valley. Proceedings of the National Academy of Sciences of the United States of America, 109, 9320-9325. https://doi.org/10.1073/pnas.1200311109

[9] Lascano, R.J. (2000) A General System to Measure and Calculate Daily Crop Water Use. Agronomy Journal, 92, 821-832. https://doi.org/10.2134/agronj2000.925821x

[10] Mahan, J.R. and Lascano, R.J. (2016) Irrigation Analysis Based on Long-Term Weather Data. Agriculture, 6, 42. https://doi.org/10.3390/agriculture6030042

[11] Lyle, W.M. and Bordovsky, J.P. (1981) Low Energy Precision Application (LEPA) Irrigation System. Transactions of the American Society of Agricultural Engineers, 24, 1241-1245. https://doi.org/10.13031/2013.34427

[12] Lyle, W.M. and Bordovsky, J.P. (1983) LEPA Irrigation System Evaluation. Transactions of the American Society of Agricultural Engineers, 26, 776-781. https://doi.org/10.13031/2013.34022

[13] Bordovsky, J.P., Lyle, W.M., Lascano, R.J. and Upchurch, D.R. (1992) Cotton Irrigation Management with LEPA Systems. Transactions of the American Society of Agricultural Engineers, 35, 879-884. https://doi.org/10.13031/2013.28673

[14] Bordovsky, J.P., Lyle, W.M. and Segarra, E. (2000). Economic Evaluation of Texas High Plains Cotton Irrigated by LEPA and Subsurface Drip. Texas Journal of Agriculture and Natural Resources, 13, 67-73.

[15] Lyle, W.M. and Bordovsky, J.P. (1995) LEPA Corn Irrigation with Limited Water Supplies. Transactions of the American Society of Agricultural Engineers, 38, 455-462. https://doi.org/10.13031/2013.27853

[16] Howell, T.A., Yazar, A., Schneider, A.D., Dusek, D.A. and Copeland, K.S. (1995) Yield and Water Use Efficiency of Corn in Response to LEPA Irrigation. Transactions of the American Society of Agricultural Engineers, 38, 1737-1747. https://doi.org/10.13031/2013.28001

[17] Bordovsky, J.P. and Lyle, W.M. (1996) LEPA Irrigation of Grain Sorghum with Varying Water Supplies. Transactions of the American Society of Agricultural Engineers, 39, 2033-2038. https://doi.org/10.13031/2013.27706

[18] Schneider, A.D. and Howell, T.A. (1998) Methods, Amounts, and Timing of Sprinkler Irrigation for Winter Wheat. Transactions of the American Society of Agricultural Engineers, 40, 137-142. https://doi.org/10.13031/2013.21258

[19] Lyle, W.M. and Dixon, D.R. (1977) Basin Tillage for Rainfall Retention. Transactions of the American Society of Agricultural Engineers, 20, 1013-1017. https://doi.org/10.13031/2013.35693

[20] Jones, O.R. and Clark, R.N. (1987) Effects of Furrow Dikes on Water Conservation and Dryland Crop Yields. Soil Science Society America Journal, 51, 1307-1314. https://doi.org/10.2136/sssaj1987.03615995005100050039x

[21] Baumhardt, R.L., Wendt, C.W. and Keeling, J.W. (1993) Tillage and Furrow Diking Effects on Water Balance and Yields of Sorghum and Cotton. Soil Science Society America Journal, 57, 1077-1083. https://doi.org/10.2136/sssaj1993.03615995005700040033x

[22] Spooner, A.E., Caviness, C.E. and Spurgeon, W.I. (1958) Influence of Timing of Irrigation on Yield, Quality and Fruiting of Upland Cotton. Agronomy Journal, 50, 74-77. https://doi.org/10.2134/agronj1958.00021962005000020005x

[23] Turner, J.H., Ramey Jr., H.H. and Worley Jr., S. (1976) Relationship of Yield, Seed Quality, and Fiber Properties in Upland Cotton. Crop Science, 16, 578-580. https://doi.org/10.2135/cropsci1976.0011183X001600040038x 
[24] Onder, D., Akiscan, Y., Onder, S. and Mert, M. (2009) Effect of Different Irrigation Water Level on Cotton Yield and Yield Components. African Journal of Biotechnology, 8, 1536-1544.

[25] Allen, R.G., Walter, I.A., Elliott, R., Howell, T.A., Itenfisu, D. and Jensen, M. (2005) The ASCE Standardized Reference Evapotranspiration Equation. Task Committee on Standardization of Reference Evapotranspiration Environmental and Water Resources Institute of the American Society of Civil Engineers, $70 \mathrm{p}$. https://www.kimberly.uidaho.edu/water/asceewri/ascestzdetmain2005.pdf

[26] Jensen, M.E. (1968) Water Consumption by Agricultural Plants. In: Kozlowski, T.T., Ed., Water Deficits in Plant Growth, Vol. 2, Academic Press, New York, 1-22.

[27] Bordovsky, J.P. and Lyle, W.M. (1996) Protocol for Planned Soil Water Depletion of Irrigated Cotton. In: Camp, C.R., Sadler, E.J. and Yoder, R.E., Eds., Evapotranspiration and Irrigation Scheduling, Proceedings of the International National Conference, American Society of Agricultural Engineers, St. Joseph, 210-206.

[28] Grimes, D.W., Dickens, W.L. and Yamada, H. (1978) Early-Season Water Management for Cotton. Agronomy Journal, 70, 1009-1012. https://doi.org/10.2134/agronj1978.00021962007000060029x

[29] Grimes, D.W. and Dickens, W.L. (1974) Dating Termination of Cotton Irrigation from Soil Water-Retention Characteristics. Agronomy Journal, 66, 703-404. https://doi.org/10.2134/agronj1974.00021962006600030020x

[30] Nelson, J.M., Briggs, R.E. and Hart, G. (1989) Effect of Irrigation Termination Date on De-foliation and Yield of Upland Cotton. College of Agriculture, University of Arizona, A College of Agriculture Report, Cotton, 61-64.

[31] Allen, C.T., Kelley, S.R., Watson, R. and Kharboutli, M.S. (2000) COTMAN Irrigation Termination Studies. Proceedings Beltwide Cotton Production Research Conference Meeting, 146-149.

[32] Tronstad, R., Silvertooth, J.C. and Husman, S. (2003) Irrigation Termination of Cotton: An Economic Analysis of Yield, Quality, and Market Factors. The Journal of Cotton Science, 7, 86-94.

[33] Silvertooth, J.C., Galadima, A. and Tronstad, R. (2005) Evaluation of Irrigation Termination Effects on Yield and Fiber Quality of Upland Cotton, 2004. Arizona Cotton Report (P-142) May 2005, 31-46.

[34] Reeves, H.R. (2012) Effects of Irrigation Termination Date on Cotton Yield and Fiber Quality. Master Thesis, Texas Tech University, $54 \mathrm{p}$.

[35] Porter, W.M., Collins, G.D., Byrd, S.A. and Snider, J.L. (2015) Irrigation Termination and Fiber Quality: Subsurface Drip Irrigation versus Overhead. Proceedings Beltwide Cotton Production Research Conference, Technical Paper, San Antonio, 5-7 January 2015, 53-62.

[36] Buttar, G.S., Aujla, M.S., Thind, H.S., Singh, C.J. and Saini, J.S. (2007) Effect of Timing of First and Last Irrigation on the Yield and Water Use Efficiency in Cotton. Agricultural Water Management, 89, 236-242.

[37] Wanjura, D.F. and Supak, J.R. (1985) Temperature Methods for Monitoring Cotton Development. Proceedings Beltwide Cotton Production Research Conference, New Orleans, 6-11 January 1985, 369-372.

[38] Peng, S., Krieg, D.R. and Hicks, S.K. (1989) Cotton Lint Yield Response to Accumulated Heat Units and Soil Water Supply. Field Crops Research, 19, 253-262.

[39] Waddle, B.A. (1984) Crop Growing Practices. In: Kohel, R.J. and Lewis, C.F., Eds., Cotton, American Society of Agronomy, Crop Science Society of America, and Soil Science Society of America, Madison, 233-263. 
[40] Kerby, T.A., Keeley, M. and Johnson, S. (1987) Growth and Development of Acala Cotton. University of California, Division of Agriculture and Natural Resources, Bulletin 1921.

[41] Robertson, W.C. and Roberts, B.A. (2010) Chapter 4 Integrated Crop Management for Cotton Production in the 21st Century. In: Wakelyn, P.J. and Chaundry, M.R., Eds., Cotton: Technology for the 21 st Century, International Cotton Advisory Committee.

[42] Esparza, A.M., Gowda, P.H., Baumhardt, R.L., Marek, T.H. and Howell, T.A. (2007) Heat Unit Availability for Cotton Production in the Ogallala Aquifer Region of the United States. The Journal of Cotton Science, 11, 110-117.

[43] Baker, J.T. (2007) Cotton Seedling Abrasion and Recovery from Wind Blown Sand. Agronomy Journal, 99, 556-561. https://doi.org/10.2134/agronj2006.0256

[44] Cotton, Inc. (2013) The Classification of Cotton. 32 p. http://www.cottoninc.com/fiber/quality/Classification-Of-Cotton/Classing-booklet. pdf

[45] Wanjura, D.F., Upchurch, D.R. and Mahan, J.R. (1990) Evaluating Decision Criteria for Irrigation Scheduling of Cotton. Transactions of the American Society of Agricultural Engineers, 33, 512-518. https://doi.org/10.13031/2013.31359

[46] Wen, Y., Rowland, D.L., Piccinni, G., Cothren, J.T., Leskovar, D.I., Kemanian, A.R. and Woodard, J.D. (2013) Lint Yield, Lint Quality, and Economic Returns of Cotton Production under Traditional and Regulated Deficit Irrigation Schemes in Southwest Texas. The Journal of Cotton Science, 17, 10-22.

[47] Gerik, T.T., Oosterhuis, D.M. and Tolbert, H.A. (1998) Managing Cotton Nitrogen Supply. Advances in Agronomy, 64, 115-147.

[48] Pettigrew, W.T. (2001) Environmental Effects on Cotton Fiber Carbohydrate Concentration and Quality. Crop Science, 41, 1108-1113. https://doi.org/10.2135/cropsci2001.4141108x

[49] Johnson, R.M., Downer, R., Bradow, J.M., Bauer, P.J. and Sadler, E.J. (2002) Variability in Cotton Fiber Yield, Fiber Quality and Soil Properties in a South Eastern Coastal Plain. Agronomy Journal, 94, 1305-1316. https://doi.org/10.2134/agronj2002.1305

[50] Reddy, K.R., Koti, S., Davidonis, G.H. and Reddy, V.R. (2004) Interactive Effects of Carbon Dioxide and Nitrogen Nutrition on Cotton Growth, Development, Yield and Fiber Quality. Agronomy Journal, 96, 1148-1157. https://doi.org/10.2134/agronj2004.1148

[51] Meredith Jr., W.R. and Bridge, R.R. (1973) Yield, Yield Component and Fiber Property Variation of Cotton (Gossypium hlrsutum L.) within and among Environments. Crop Science, 13, 307-312. https://doi.org/10.2135/cropsci1973.0011183X001300030006x

[52] Patterson, A.H., Saranga, Y., Menz, M., Jiang, C.-X. and Wright, R.J. (2003) QTL Analysis of Genotype $\times$ Environment Interactions Affecting Cotton Fiber Quality. Theoretical Applied Genetics, 106, 384-396. https://doi.org/10.1007/s00122-002-1025-y

[53] Read, J.J., Reddy, K.R. and Jenkins, J.N. (2006) Yield and Fiber Quality of Upland Cotton as Influenced by Nitrogen and Potassium Nutrition. European Journal of Agronomy, 24, 282-290. 


\section{List of Symbols}

DOY: Day Of Year

HU: Daily Heat Units

$\mathrm{K}_{\mathrm{c}}$ : Crop Coefficient

LEPA: Low Energy Precision Application

SD: Standard Deviation

THP: Texas High Plains

¿HU: Cumulative Daily Heat Units

$\mathrm{T}_{\text {min }}$ : Daily minimum air temperature $\left({ }^{\circ} \mathrm{C}\right)$

$\mathrm{T}_{\max }$ : Daily maximum air temperature $\left({ }^{\circ} \mathrm{C}\right)$

$\mathrm{T}_{\mathrm{t}}$ : Threshold temperature $\left(15.6{ }^{\circ} \mathrm{C}\right)$

Submit or recommend next manuscript to SCIRP and we will provide best service for you:

Accepting pre-submission inquiries through Email, Facebook, LinkedIn, Twitter, etc. A wide selection of journals (inclusive of 9 subjects, more than 200 journals)

Providing 24-hour high-quality service

User-friendly online submission system

Fair and swift peer-review system

Efficient typesetting and proofreading procedure

Display of the result of downloads and visits, as well as the number of cited articles

Maximum dissemination of your research work

Submit your manuscript at: http://papersubmission.scirp.org/

Or contact ojss@scirp.org 